\title{
The Script of the Dove: An Armenian Hetaerogram
}

\section{Citation}

Russell, James R. 2010. "The script of the dove: An Armenian hetaerogram." Journal of Armenian Studies 9, nos. 1-2: 61-108.

\section{Permanent link}

http://nrs.harvard.edu/urn-3:HUL.InstRepos:12337824

\section{Terms of Use}

This article was downloaded from Harvard University's DASH repository, and is made available under the terms and conditions applicable to Open Access Policy Articles, as set forth at http:// nrs.harvard.edu/urn-3:HUL.InstRepos:dash.current.terms-of-use\#OAP

\section{Share Your Story}

The Harvard community has made this article openly available.

Please share how this access benefits you. Submit a story.

Accessibility 


\title{
THE SCRIPT OF THE DOVE:
}

\section{AN ARMENIAN HETAEROGRAM.}

\author{
By James R. Russell, \\ Harvard University.
}

Cryptography, the study of codes, ciphers, and the storage and transmission generally of information in a secret manner, is a science now dominated by mathematicians with computers, rather than an aspect of textual and historical research studied mainly by philologists and palaeographers, as it was in the past. It is reasonable that this should be so: as human technology has become more sophisticated and complex, secret codes have become an important feature of the security and military capability of states. The decipherment by Alan Turing and others of the German Enigma code helped the Allies defeat Hitler in the Second World War. ${ }^{1}$ Protection of the security of internet communications, financial and other, against viruses and hackers, is an issue that affects many aspects of life today. But in scholarship one must steadily resist as fallacy the impression that because we have over time developed more complex machines now than our ancestors did, it follows that we are more intelligent than they were. The writings of the ancients are still our fundamental classics; and even in the field of cryptography, the mastery of the men of the past endures. For it is after all a mediaeval cipher, not the mechanized encryption of a modern intelligence service, that still resists the combined efforts of scholars and scientists to decipher it. The Voynich MS, a book written entirely in an unknown code and illustrated with enigmatic anatomical, astronomical, and mechanical pictures, is perhaps the most popular manuscript in the world: drawings of what look like the cellular walls of the skin, and the structure of galaxies, have proved particularly intriguing and controversial, since the manuscript undoubtedly predates the invention of microscope and telescope. It belongs to the Beinecke rare book library of

\footnotetext{
${ }^{1}$ On cryptography generally, the best book is still David Kahn's magisterial The Code-Breakers, New York: Macmillan, 1967. Andrew Hodges in his biography Alan Turing: The Enigma, New York: Simon and Schuster, 1983, discusses how Turing's work on code-deciphering machines during World War II led to the invention of the computer. But with the onset of the Cold War, Turing's left-wing convictions and homosexuality isolated him from the authorities and society and led to his untimely death.
} 
Yale University, the American National Security Council and Bell Labs are among the institutions that have commissioned studies of it, at least one scholarly career has been wrecked by a failed and misguided decipherment of it - and to this day nobody has any idea what it says. ${ }^{2}$

The writing in the Voynich MS, if it was not from the start a sort of scholastic joke with no plain text behind the encrypted one, must then be a code of extraordinary complexity, probably involving either an artificial language or a permutated natural one. The simplest codes, by contrast, are substitution ciphers, in which a symbol, number, or other letter is substituted for a letter of the alphabet in transcribing straightforwardly the spelling of a word in a natural language. When the language in question is English, it is a simple matter to crack the code, if the enciphered text is of moderately sufficient length, by counting the occurrences of each symbol and then applying the list of frequency of letters in our language: etaon irshd lucmpf jkqxz. A few years ago a dealer in antiques in New England sent me out of the blue several photographs of a painting handed down as an heirloom in his family. It is a still life - a glass vase of flowers - in oils: it looked to its owner, and to me, as though it might be the work of an artist living in the Ottoman Empire in the middle or late $19^{\text {th }}$-century. Armenian artists of that place and period in particular combined Western European expertise in technique with Near Eastern subjects and sensibilities; so it would not be unreasonable to surmise that the painter might have been an Armenian. ${ }^{3}$ What interested the owner of the picture was not so much the provenance of the picture as this: someone had incised short inscriptions into the lower part of the painting and across the back, and nobody he had consulted could tell him what language it was. Several of his interlocutors ${ }^{4}$ knew I taught Armenian and were

\footnotetext{
${ }^{2}$ See Gerry Kennedy and Rob Churchill, The Voynich Manuscript, London: Orion, 1992.

${ }^{3}$ A number of Armenian artists working in the Ottoman Empire in the late $19^{\text {th }}$ century painted such still life oils, though with greater technical expertise: Ōženi K'awuk ‘čean, Anton Mkrean, Eruand Ōskan, and Batist Limončean come to mind. See Garo Kürkman, Armenian Painters in the Ottoman Empire, 1600-1923, 2 vols., Istanbul: Metusalem, 2004. For the painting and cipher inscription see Plates 4-7 in this essay. A few characters and the first two lines and bottom of the longer inscription on the back of the panel are blurred; and the individual symbols to the left may be numeration of some kind. But the bulk reads: "I met al.../ Just opened to the morning .../ And so I stopped to gaze/ And thou art beautifull [sic!] I said/ That lily did not hide its head/ But freely forth its odors shed/ To pay me for my praise." The shorter inscription on the painting itself reads, "... face to look upon and pray.../ ... spirit keep thee..."

${ }^{4}$ I never learnt the identity of these mysterious friends; but a curious incident is worth retelling here. Not long after I first came to Harvard, in 1993, a person unknown at Widener Library forwarded to me for reply a letter of inquiry from the north of England about the Necronomicon. The American writer of fantastic fiction H.P. Lovecraft (d. 1937,
} 
apparently aware as well of the pleasure I took in puzzling over arcane writing; and suggested he contact me. Upon receipt of his photographs, the first thing I noticed was that some letters obviously derived from the Runic alphabet of northern Europe. I therefore hypothesized that the code was of a Western European language. The words of the inscriptions are helpfully separated by dots, and from a cursory survey of the two-tofour-letter words I hazarded the guess that these were the definite articles, prepositions, and conjunctions of English. I then poured myself a peg of Scotch (Sherlock Holmes would have lit a pipe) and deciphered the message in a few minutes. ${ }^{5}$ It is a rather banal, sententious poem of the sort a provincial American (and a rather vulgar one- he was after all defacing a painting that is not without a simple and affecting charm) of the Victorian age might have liked. Thus the painting might have been purchased as a souvenir in an Ottoman city frequented by Western travelers, most likely Constantinople or Smyrna. I have not seen the code elsewhere; so it is at least possible that the writer of the text invented it himself and maybe even used it just this once. But where would he have found the symbols for it? One surmises they could easily have been culled from another cipher, maybe that ${ }^{6}$ of one of the semi-secret fraternal societies that were very popular in the United States in the period. ${ }^{7}$

Providence, RI) invented and wrote about this (unfortunately) fictional tome of dread occult lore in his story "The Dunwich Horror", which blends the invented with the real. Dunwich itself is a sunken city off the east coast of England; and Lovecraft's Massachusetts town of that name is inspired by a real village submerged by a reservoir near Amherst. As for the book, the story claims copies carefully kept from the public eye belong to the collections of Miskatonic University (fictional) and Harvard's Widener Library. The story also mentions a cipher passed down by a secretive cult - just the phenomenon that is the topic of this essay! It was my sad duty to inform our British correspondent that although in his house at R'lyeh dead Cthulhu waits dreaming, there is no Necronomicon at Widener. ${ }^{5}$ This part of decipherment, the cultivated hunch, is the Fingerspitzgefiuhl that comes with formal training if one is lucky. It goes back a long way: al-Khalīl of Bașra, eighth century, solved an encrypted Greek message sent as a condescending tease by the Byzantine emperor. The Arab scholar thought it must begin with a formula "In the name of God" or words to that effect. It did, and he got the first letters of the code that way: see Kahn, op. cit., p. 97.

${ }^{6}$ American Freemasons, then as now, work the Craft rituals "to an approved ritual issued to them in cipher": Bernard E. Jones, Freemasons' Guide and Compendium, London: Harrap, 1956, p. 226.

${ }^{7}$ Mark C. Carnes, Secret Ritual and Manhood in Victorian America, New Haven: Yale University Press, 1989, suggests the Masonic order and other groups affirmed their members' masculinity while the churches and other institutions of the fast-growing industrial Republic undermined and threatened it. At the same time, the revelation of the "Royal Secret" of our hermaphroditic nature provided release for sexual emotions that could not be expressed otherwise or elsewhere in Victorian society. Although some of Carnes' insights have undoubted validity, they seem informed less by a standard of impartial scholarship than by the agenda of gender studies. The author's work is marred by an almost cartoonish contempt for the organizations he is studying, and throughout the book he seems to assume $a$ priori that sane, mature men cannot have serious spiritual or mystical strivings. On page two, for instance, he summarily dismisses the rituals and teachings of the secret orders as "hokum". One need but reflect that the latter word is itself a Victorian product of British colonial usage in India: Arabic hukm, "an order" (see Henry Yule and A.C. Burnell, Hobson-Jobson: a Glossary of Colloquial Anglo-Indian Words and Phrases, 1886, London: Routledge and Kegan Paul, repr. 1986, p. 424) became for the Westerner good slang for nonsense! Such an attitude in any other context toward a culture or religion under study would be regarded as a disqualification of the researcher from further serious scientific work: one shudders to think what such a scholar might do to Sufism in Islam, or Kabbala. 
Those societies, with their secret rituals and signs of recognition, satisfied a need to belong and to feel special, apart from the ignorant herd; and one aspect of their operations was the use of ciphers to endow their communications with a sense of privacy, prestige, and mystery. Those are precisely the conditions under which one proposes the kind of Armenian cipher to be discussed, which I will term a "hetaerogram", would have developed and flourished. Indeed in America the exposure of the secrets of one such secret society, the Ku Klux Klan, was more a factor in its downfall than any diminution of its violent activity. ${ }^{8}$ Secrecy has an incomparable allure.

Some ciphers invented by one person for his own use and never employed by anyone else derive their symbols from historical sources, as in the case of the painting. A substitution cipher attested uniquely in the Folger Manuscript, devised by a medical doctor in New York, 1827, to write about Masonic philosophy uses different simple symbols representing the individual letters. But the inventor put them together in such a way as to have each word form a squared design resembling somewhat Egyptian hieroglyphics: the inventor even uses the Egyptian convention of the cartouche to enclose words of special significance. The cipher thus reflects both the fashion of aegyptomania in early $19^{\text {th }}$-century America and the inherent secretiveness of the Masonic order, as well as of course the Masonic interest in primordial culture. ${ }^{9}$ Masonic secrecy, which has its own social and religious value independently of any public or political stimuli, became a practical and urgent matter in Folger's day. For this was the period of the anti-Masonic movement following the Morgan Affair of 1826 - a year before Folger composed his MS. ${ }^{10}$ A man named Morgan in upstate New York was abducted and apparently murdered by Lodge brethren, for having divulged Masonic secrets. So the arcane and the

\footnotetext{
${ }^{8}$ See Steven D. Levitt and Stephen J. Dubner, Freakonomics: A Rogue Economist Explores the Hidden Side of Everything, New York: Harper Collins, 2006, p. 58.

${ }^{9}$ As one author has put it, combining Proust with the Masonic quest, à la recherché $d u$ verbe perdu.

${ }^{10} \mathrm{~S}$. Brent Morris, The Folger Manuscript: The Cryptanalysis and Interpretation of an American Masonic Manuscript, Bloomington, IN: The Masonic Book Club, 1992, published the entire text in facsimile, with facing plain text: see Plates 1-3 accompanying this study. On the Egyptomanic craze and American literature, cf. John T. Irwin, American Hieroglyphics: The Symbol of the Egyptian Hieroglyphics in the American Renaissance, New Haven: Yale University Press, 1980: Poe's Antarctic traveler Arthur Gordon Pym encounters mysterious Ethiopic, Coptic, and Arabic inscriptions on his journey portending doom and various reflecting Hebrew tsalmaweth, the shadow of death, see pp. 195-205.
} 
mysterious are a lure to prospective members of secret societies; but sometimes those societies, whether embroiled in scandal or condemned by some powerful establishment of religion, also have good and practical reasons to try to protect their members by keeping their communications secret.

Sometimes the mere difficulty of a known script can be counted on as a sufficient deterrent to undesired intrusion into writings of a personal nature. In the mid-1 $7^{\text {th }}$ century, the English politician Samuel Pepys used a system of shorthand to write the several volumes of his famously candid diaries: the system was published but might as well have been a secret code to the untutored. ${ }^{11}$ Invented scripts are sometimes associated with invented languages with their purpose not so much discretion as literary invention or plain fun: the British fantasy writer and mediaevalist J.R.R. Tolkien used an angular Runic alphabet and a delicately curvaceous cursive script called Tengwar or Quenya to write his various made-up languages in The Lord of the Rings and other books. The palaver of his Elves, indebted to Old English, also owes much of its euphony to Finnish; whilst the sinister inscription on the Ring of Power in the dark tongue of Mordor, jabbered by cruel and ugly Orcs, is endowed with the agglutinative character and phonetic signature, I think, of Turkish. ${ }^{12}$

Another interesting example of a cryptogram invented by a writer for his own use, employing some esoteric symbols or characters from foreign writing systems, is the cipher of the Russian writer Daniil Kharms (the nom de plume of Daniil Ivanovich Yuvachev, 1905-1942), a member of the OBERIU literary circle in Leningrad. Like many other Soviet citizens, he fell afoul of the Stalinist authorities: Kharms died of starvation, imprisoned in a mental hospital, during the Nazi blockade. Though he is best known as the author of absurdist poems, plays, children's literature, sketches, and short stories, Kharms was also an inspired artist with an avid interest in ancient Egypt,

\footnotetext{
${ }^{11}$ The system is published in Thomas Shelton, A Tutor to Tachygraphy, or Short-Writing, London, 1642.

${ }^{12}$ On invented languages and their scripts generally, including Tolkien's, see Paolo Albani and Berlinghiero Buonarroti, Aga Magéra Difúra: Dizionario delle Lingue Immaginarie, Bologna: Zanichelli, 1994. The idea that the northern races are noble; the southern, base - is a pernicious sort of racism that suffuses also the Narnia books of Tolkien's Oxford friend, C.S. Lewis. See J.R. Russell, "News from Zembla," a review article on John Garth, Tolkien and the Great War, Elena Obatnina, Tsar' Asyka i ego poddannye, etc., The New Leader, New York, Summer 2004.
} 
Kabbalah, the mystical properties of the Hebrew alphabet, and kindred occult subjects the same range of interests, that is, that animated the Masons of Folger's day and that one will observe presently in the case of the Order of the Golden Dawn. Several characters of the private cipher he invented are the same as those of the cipher employed by members of that order; others come from Japanese; and one seems to derive from the Samaritan Hebrew script. Some of the encoded entries in his diaries are of sexual content - a good reason for secrecy - and eavesdropping by others was the first stage of the pervasive culture of surveillance in the Soviet Union, though one rather thinks a secret code would have sparked, not deterred, the malign attention of police informers. ${ }^{13}$

Russia brings us a little closer to Armenia; and indeed the creation of new languages, some with their own scripts, has never been limited to the West. Zoroastrian sectarians in India, followers of Dastur Azar Kaivan, who flourished in the reign of the emperor Akbar, several centuries ago invented an artificial language for the book of their traditions and teachings, the Desātir. ${ }^{14}$ In a Perso-Turkish milieu of around the $15^{\text {th }}$ or $16^{\text {th }}$ century there was created a language for the use of mystics called Bāl-a i-Balan: it displays characteristics of the languages of its inventors, and was probably invented to conceal esoteric teachings from censorious orthodox divines. ${ }^{15}$ There is, in the Armenian sphere, the interesting case of a reclusive gentleman of Smyrna, Petros T'nkər(ean) (or Tenger, d. 1881), who had studied with the Vienna Mekhitarists, an Armenian Catholic monastic order dedicated to scholarship, and had mastered the principal languages of Western Europe and the Ottoman Empire, as well as Sanskrit. Tenger settled in a stone house on a hill in the Aspra Khomata district of his native city and dwelt there in seclusion: he devised a new language, called Sahleray [pronounced Sahlerá], with its own alphabet and grammar. He had the custom of presenting copies of a textbook of his new language, presumably privately published in an edition of a modest print run, to the

\footnotetext{
${ }^{13}$ See Plates 10-14 here; cf. Aleksandr Nikitaev, "Tainopis' Daniila Kharmsa: opyt deshifrovki" ["The cipher of Daniil Kharms: an attempt at decipherment"], in Yu. S. Aleksandrov, ed., Risunki Kharmsa ["Kharms' Drawings"], St. Petersburg: Ivan Limbakh, 2006, pp. 237-247; and Zh.-F. Zhakkar, ed., Daniil Kharms, Zapisnye knizhki, Dnevnik ["Notebooks, Diary"], 2 vols., St. Petersburg: Akademicheskii Proekt, 2002.

${ }^{14}$ See J.R. Russell, "On Mysticism and Esotericism among the Zoroastrians," Iranian Studies 26.1-2, 1993, pp. 73-94, esp. p. 87, repr. in J.R. Russell, Armenian and Iranian Studies [=AIS], Harvard Armenian Texts and Studies 9, Cambridge, MA, 2004.

${ }^{15}$ Alessandro Bausani, “About a curious mystical language Bāl-a i-Balan,” East and West, Year IV, No. 3, Rome: IsMEO, 1954, pp. 234-238.
} 
(presumably few) guests who penetrated his fortress. A sign inscribed in the Sahleray language and script with the word Ayzeratand, meaning "Temple of Wisdom", hung over the entrance to the visionary linguist's mystic lair. ${ }^{16}$ It is not clear whether Tenger intended his new idiom to be an international tongue to promote human unity, as Dr. Zamenhof of Warsaw did with Esperanto. At least, the former never made any real attempt, as far as is known, to popularize Sahleray.

But it may be surmised at least that these imaginative representatives of two harassed and disfranchised minority nations - the Jew from Russian Poland and the Armenian in Western Anatolia - were in part attempting by inventing languages they could control to compensate for the feelings occasioned by the impotence and unofficial status of their own native tongues, each with its distinctive script (Armenian, for Armenian and Armeno-Turkish; and Hebrew, for Hebrew and Judaeo-German or Yiddish). ${ }^{17}$ Tolkien, an Oxford don, felt no such insecurity; but for him, too, as he admitted in a lecture of $c a .1930$, the invention of languages was an eccentricity and a matter of pleasure, and of a sort of guilty, boyish pleasure at that. ${ }^{18}$ So invented scripts, as we have seen so far, tend to fulfill certain, similar needs: a member of a secret society seeks a sense of belonging and of validation. A religious sect endows its new writings with the patina of ancient prestige through the invention of esoteric scripts and words. A member of a belabored small people whose own language and script are without honor in the macrocosm creates a language or script of his own that he can magnify and control in his own microcosm. An academic reluctant to part entirely with adolescence retains its need for self-aggrandizing, romantic secrets such as codes others cannot read, and

\footnotetext{
${ }^{16}$ Abraham Ayvazean, Šar hay kensagrut'eanc', Constantinople, 1893, part II, pp. 91-95; and Fr. Ep'rem Pōłosean, Guyumčean ew T'ankarean gerdastannerə [German title, Die Familien Kouyoumdjian und Tingir; Tenger is another known spelling of the latter surname], Vienna: Mxit'arean tparan, 1951, pp. 34-39. I have been unable to locate a copy of Tenger's textbook, but one may exist in the Mekhitharist library at Vienna.

${ }^{17}$ The life of Ludovic Lazarus Zamenhof, 1859-1916, in many respects parallels that of Eliezer Ben Yehuda, to be discussed presently. Both were Russian Jews, and both associated their imaginative linguistic projects with an ideology. In 1901, Zamenhof published in Russia a book, Hillelism, in which he outlined an idealistic philosophy of universalist, humanist liberalism taking its name from the gentle Jewish sage Hillel: see Marjorie Boulton, Zamenhof: Creator of Esperanto, London: Routledge and Kegan Paul, 1960, p. 98 f. Esperanto was to be the language of this utopian (and unrealizable) cosmopolis, even as Hebrew was to be the speech of the reborn commonwealth of Israel. One recalls that Thomas More created for the perfect society of his Utopia an alphabet of ideally simple geometric shapes, in its way like Zamenhof's pleasantly simple language.

${ }^{18}$ J.R.R. Tolkien, "A Secret Vice," in Christopher Tolkien, ed., The Monsters and the Critics and Other Essays, Boston: Houghton Mifflin, 1984, pp. 198-223.
} 
magical-sounding incantations outsiders cannot understand: through these he hopes to gain others' awed attention, their respect, maybe even their love.

As we have seen, the sheer force of the imagination, employed to serve a profound psychological need - the thirst for inner self-fulfillment, for validation of one's status and integrity - has brought forth cryptograms used by individuals and sodalities, as well as languages and scripts created for fiction and artificial languages intended for use worldwide. The act of creative imagination is as crucial to a related phenomenon of much greater historical importance: the revival of ancient or degraded languages, such as Hebrew or Armenian alluded to above, with their native scripts, for modern, secular use in the setting of a newly-created nation-state. Language is an inestimable component of the project of nationalism: an imagined, shaped identity needs not only the practical appurtenances of territory and state power to administer and defend it, but an idea and a voice to animate the society defined within international frontiers. That is, nationalism needs ideology and language. In the case of the Armenians, it is fairly evident from the hagiography of Maštoc ' by Koriwn that the visionary activity of the saint in creating a script for Armenian in the fifth century served a palaeo-nationalistic end, giving a standard literary language to a polity on the threshold of the loss of political sovereignty. ${ }^{19}$ And in the modern period, two great modernizers of Armenian, Mesrop T'ałiadeanc' and Xač'atur Abovean (the latter the author of the first "modern" Armenian novel, Vērk' Hayastani, "The Wounds of Armenia", 1848) were isolated and traumatized men moved by a powerful inner vision verging on passion. Before them, the Mxit'arist reforms of the language had been grounded in classicism and were not connected to any movement of national liberation: the good Catholic fathers, living in distant Venice and Vienna, were largely content with Diaspora circumstances and saw no prospect of an end to Ottoman rule. They were mainly unconcerned with the political fate of the Armenian highland, a country most of them had never seen. But these two men set out to transform Armenian, a cluster of mutually unintelligible dialects burdened by thousands of loan-

\footnotetext{
${ }^{19}$ On this subject, see J.R. Russell, "On the Origins and Invention of the Armenian Script," Le Muséon 107.3-4, 1994, pp. 317-333 (repr. in AIS, pp. 565-581); and on early Armenian nationalism see J.R. Russell, review of Razmik Panossian, The Armenians: From Kings and Priests to Merchants and Commissars, New York: Columbia University Press, 2006 in The American Historical Review 112, Bloomington, IN, 2007.
} 
words from the languages of Muslim overlords and neighbors, into a standardized, modern literary idiom capable self-sufficiently to construct neologisms much as the literary language of Maštoc' had become - and to become the vehicle of national liberation and the forging of a free Armenian state.

Jewish history seems so often to run parallel to that of the Armenians that the crucial, intriguing differences sometimes seem to jump out at one unexpectedly. Most Armenians inhabited their ancient homeland but were oppressed by Muslims and looked to the Christian powers for help; the Jews lived in exile from their country in Christian lands that were hostile ipso facto, while Palestine was governed by the relatively benign Ottomans. Yet here are the similarities: rather like the promoters of the Mxit'arist project, the European Jews of the Enlightenment, the maskīlìm, sought to standardize and modernize the Hebrew language. But their main goal in this was to enable their fellow Jews to imbibe secular culture and thereby to become assimilated into the nations of the Diaspora as a minority stripped of the lineaments of its ancient separateness. They did not foresee that their efforts were often one-sided: the ambitious, assimilated, secular Jew was to appear to hostile eyes more insidious and threatening than the ghettoized one of a generation before. However the linguistic reformer Eliezer Ben Yehuda saw the question differently, and attempted in the final quarter of the $19^{\text {th }}$ century to shape a revived Hebrew that Jews might employ for their own everyday purposes, without sacrificing their identity, in their own country. Ben Yehuda himself emigrated to Jerusalem from Russia, and was excommunicated by the local rabbinate, much as Abovean had been anathematized by the Armenian Church. But Ben Yehuda persisted: he raised his children to hear only Hebrew, he wrote a dictionary, and the living speech of Israel today owes its existence to him. But he came to his vision - and to his traumatic fate - not only from a study of history, or an interest in linguistics, but from reading, in the Russian journal Vestnik, about a work of fiction.

The Englishwoman who published under the male nom de plume George Eliot wrote her last, great novel, Daniel Deronda, about a young man gently raised in an English home who discovers his Sephardic Jewish lineage from some documents hidden 
in a chest. The psychological metaphor, of uncovering something suppressed from one's past and at the core of one's being, is too obvious to require comment. Daniel determines not only to embrace his heritage and people, but also to move to the land of Israel and to restore the Hebrew language there to its original status as a living idiom. The novel was translated into Russian in its ponderous Victorian entirety by Perets, Gordon, Smolenskii, and Lilienblum in the 1880's: these men, who had at first advocated assimilation, abandoned the idea in the wake of Tsar Alexander III's pogroms and themselves made aliya, "ascent", to Israel. ${ }^{20}$ The novel is not merely a leap of imagination, an invention of Zionism avant la lettre; it turns out to have been also the spark that fired Eliezer Ben Yehuda to move in the direction he did. In retrospect, the Jewish state without Hebrew seems inconceivable. ${ }^{21}$ Having a collective speech and script in a country of your own is as important as having that room of one's own Virginia Woolf was to demand for women..$^{22}$ The continuing demonization of the Jews and Israel in the world suggests that Zionism is the most radical of national liberation movements; so it is perhaps not surprising that it should have an affinity, though sublimated, to feminism - and, one can argue, to gay liberation as well. ${ }^{23}$

\footnotetext{
${ }^{20}$ On the translation, see Solomon Hurwitz, "George Eliot's Jewish Characters," Jewish Forum 5, 1922, p. 369. Susan Meyer, "Safely to Their Own Borders: Proto-Zionism, Feminism, and Nationalism in Daniel Deronda," ELH 60.3, Autumn 1993, pp. 733-758, argues that here, as in other novels, Eliot has deflected the problems of being a woman, which she fails to challenge and resolve when she creates female characters, onto problems of "race" instead of gender; and males are produced to master these issues. She also observes that Daniel Deronda and other Jewish men in the novel actually assume feminine traits and roles.

${ }^{21}$ There is a counterfactual historical novel by Michael Chabon, The Yiddish Policemen's Union, 2007, that imagines instead of Israel a temporary refuge for Holocaust survivors at Sitka that is about to be repossessed by the state of Alaska; its inhabitants, dispersed. The tongue of these hapless, homeless Jews is that of the Diaspora- Yiddish.

${ }^{22}$ For minority peoples like Armenians and Jews, whose very right to that room of one's own is contested, and whose languages have often seemed to be endangered species, the issue is a burning one. But even the young American republic, in a far less parlous condition, was exercised by what was regarded as the urgent necessity of defining a national language and the orthography of its alphabet: see Jill Lepore, A is for American: Letters and Other Characters in the Newly United States, New York: Knopf, 2002.

${ }^{23}$ In 2007 the American gay novelist and literary scholar Edmund White published a novel, Hotel de Dream, which imaginatively expands an incident known only anecdotally from the last weeks of the life of the American writer Stephen Crane (1871-1900). According to James Gibbons Huneker, a New York art critic and friend of Crane's, the two men once saw on the street a beautiful young male prostitute whose appearance first repelled, then fascinated Crane, who took the boy home to dinner and plied him with questions about his life. He began a novel about the youth but then destroyed it under pressure from horrified friends. Though the story may be largely apocryphal, the fact is that Crane did write about a female prostitute: Maggie: A Girl of the Streets (see Stephen Crane, Prose and Poetry, New York: The Library of America, 1984). In White's novel, Crane's lost MS is called The Painted Boy, and the youth, Elliott, is unashamedly gay and unassimilated to the breeder world. When at a reading and discussion of Hotel de Dream at the Brattle Theatre in Cambridge, MA one asked White whether his imagined novel might be viewed as a sort of Daniel Deronda of gay liberation, he warmly agreed and reminded me that he had written the introduction to the Modern Library Classics edition of George Eliot's novel (New York: Random House, 2002, pp. i-xxv).
} 
There are other ciphers of the substitution kind, employed not for invented but for natural languages, which have been used, not by a single writer, but by many different people over the course of centuries - in the cases we are to examine, as long as nearly half a millennium. Though they are essentially cryptograms, in that they are intended to have a veneer of secrecy, and though they employ symbols considered to be of esoteric symbolic importance or else have esoteric designations, they cannot truly be said to be secret, given their long and wide employment. They are certainly not the guilty, pleasurable effluence of a solitary vice; so some other term must be devised better to characterize and understand them. I propose here a neologism, hetaerogram - by which term I mean an invented script employed to represent a natural language whose users draw, or claim to draw, upon a tradition of antiquity, that also belongs, not to one user, but to a hetaira, that is, in Greek, some association or sodality of people, or to several groups; and that is employed also not for a single occasion but over a significant period of time. Moreover, despite its wide and long application, the script never emerges into the arena of entirely public employment. It retains its reputation, however undeserved, of deep secrecy. To lessen somewhat the grating effect of a novel word in the language, one intends a punning reliance upon an existing term, heterogram, by which is meant the representation of a word in one language by the same word in another. ${ }^{24}$ The users of hetaerograms would seem to see the script they share as ennobling the message of a text and setting it apart from other texts in the same language, as though they were writing the same and another language at once; and correspondingly they regard themselves as communicating in a special and privileged way.

Perhaps the most important hetaerogram in the West is the cipher that was most famously employed by the Order of the Golden Dawn of the late $19^{\text {th }}$ and early $20^{\text {th }}$ centuries, of which the Irish poet William Butler Yeats was a member. ${ }^{25}$ This substitution cipher goes back to the Polygraphia of the $16^{\text {th }}$-century abbot Johann Trithemius and is

\footnotetext{
${ }^{24}$ In Zoroastrian Book Pahlavi, or Middle Persian, for instance, cursive, connected Aramaic letters forming the Aramaic word $M L K A$ represent, and are read as, Persian $̌ a ̄ h$, "king". In English, the ampersand symbol (\&) meaning "and" is actually a shorthand heterogram of Latin $e t$.

${ }^{25}$ See Darcy Küntz, The Complete Golden Dawn Cipher Manuscript, Edmonds, WA: Holmes Publishing Group, 1990. A key to the cipher is provided also by Nigel Pennick, Magical Alphabets, York Beach, ME: Samuel Weiser, 1992, p. 181 , as a "Renaissance magical alphabet".
} 
composed mainly of alchemical symbols. Some symbols present in the cipher had been employed earlier by Chaucer in a secret code of his own. ${ }^{26}$ John Dee, the Elizabethan occultist and magician, owned a copy of Trithemius' Steganographia and knew the Polygraphia as well. ${ }^{27}$ So before its employment by the Order of the Golden Dawn, this alchemists' cipher was already well known and several centuries old, with its roots older still. Its modern users could scarcely have thought it particularly secret, then; and by the modern era the decryption of a substitution cipher would have been a fairly simple matter for any interested and literate Englishman. One thinks therefore that the cipher of the Golden Dawn was not so much a cryptogram as a hetaerogram - a writing system for which an old and noble pedigree might be claimed, limited to the use of a soi disant elite. It derives its prestige, not only from its long itinerary across the ages, but also from its content - the symbols of the alchemical craft. As we shall see presently, there is in Armenian usage an analogous hetaerogram.

The Armenian hetaerogram under discussion was used mainly by physicians and herbalists, though craft guilds of other kinds employed it as well. It seems to have endured, thus, for nearly half a millennium. It is referred to in some MSS as ałuanic ' gir, "Aluan script", i.e., the alphabet devised by St. Mesrop Maštoc" for the Ałuank" or Caucasian Albanians (no relation to the Albania of the Balkans); it also bears the designation b̌̌škakan, "belonging to physicians", and has been the object of intermittent study since the late $19^{\text {th }}$ century. ${ }^{28}$ It is in fact a cipher based wholly on the shapes and

\footnotetext{
${ }^{26}$ These symbols were of course known very widely among practitioners of alchemy and the occult arts: see Fred Gettings, Dictionary of Occult, Hermetic, and Alchemical Sigils, London: Routledge \& Kegan Paul, 1981, esp. the entry "Alchemist Script", pp. 44-45, with ref. to B. de Vignere, Traicté des Chiffres, ou Secrètes Manières d'Escrire, 1586. On Chaucer's code, see Kahn, op. cit., pp. 90-91.

${ }^{27}$ Adam McLean, ed., The Steganographia of Johannes Trithemius [tr. of Books I and III only], Edinburgh: Magnum Opus Hermetic Sourceworks, 1982, p. 7. The members of the Order may not have known of Dee's familiarity with the work of Trithemius; but they saw themselves within the tradition, at any rate, of Dee: a composite cipher-symbol Dee invented for hermetic meditation and called the monas hieroglyphica (see John Dee, The Hieroglyphic Monad, New York: Samuel Weiser, 1977) is reproduced on the page of the Golden Dawn cipher MS illustrated here. One might observe also that Dee's designation reflects an early interest, in turn, in Egyptian hieroglyphics as symbols of esoteric wisdom.

${ }^{28}$ See Plates 15-18. N. Karamianz (K'arameanc'), "Einundzwanzig Buchstaben eines verlorenen Alphabets," Zeitschrift der Deutschen Morgenländischen Gesellschaft 50, 1886, pp. 315-319, studied an encoded inscription from Sivas, AD 1535, in a MS including the Armenian version of the Alexander Romance. It reads, simply, Yišec ' $\bar{e} k$ ' zmełapart Yovasap" sarkawak'n [sic! for sargawag] "Remember ye the deacon Ioasaph, the sinner." Karamianz believed the script to be genuine Aluan. Frédéric Murat returned to the inscription in his article "Nšanagirk" imastnoc ", Handēs Amsōreay 17, 1903, pp. 333-335, and concluded correctly that it was not Aluan but a simple substitution cipher based directly on Armenian.
} 
values of the Armenian alphabet, in contrast to a table of letters in a fifteenth-century Armenian MS, Erevan Matenadaran 7117, also - and more correctly - entitled ałuanic ‘ gir, that reproduces with fidelity some of the letters of the authentic Aluan script as it is now known from a recently-discovered palimpsest. ${ }^{29}$ The Aluans were converted to Christianity, and lived in such close proximity to Armenians in all respects of life and culture as sometimes to seem indistinguishable from them; yet their written language seems to have vanished utterly by the mediaeval period. So naming a cipher Aluan was to endow it with a readily recognizable aura of antiquity and mystery: the Aluans were for the Armenians the "near Other". But it would seem that Aluan was an alternative name, or perhaps a misreading of another, original name, for the cipher: *alunic" gir, "script of the dove"; for a superscription in Armenian letters above one enciphered text reads, Ays $\bar{e}$ Hayoc " hin aławnagirn, "This is the ancient dove-script of the Armenians". And the latter is claimed to have been Hayoc'Senek'erim t'agaworin hin mateannerēn ōrinakuac, "copied from one of the old books of Senek'erim, king of the Armenians." Senek'erim, i.e., Sennacherib, was a regnal name of the Arcrunids of Vaspurakan and the attribution would therefore belong to the tenth century; or else the writer perhaps had in mind the name of the Armenian king in the Epic of Sasun whose daughter, Covinar, was the mother of the twins Sanasar and Bałdasar, the first generation of the warrior heroes. This attribution to fabulous and possibly heroic antiquity of the cipher is to be seen in much the same light as its identification as the (lost) alphabet of the ancient Aluans - as a conscious effort to endow it with a prestige linked to the supernatural or to the glories and mysteries of the distant past.

The MS so described was kept at Eudocia (Tokat), central Anatolia. The owner, one Dawit' Širinean, copied the cipher text on paper and sent it to his brother Tigran in Sebastia (Sivas). The latter sent it to the scholar Karapet Gabikean ${ }^{30}$ in 1908. The latter

\footnotetext{
${ }^{29}$ Zaza Aleksidzé and Jean-Pierre Mahé, "Découverte d'un texte albanien: une langue ancienne du Caucase retrouvée," Académie des Inscriptions et Belles-Lettres, Comptes Rendus, Paris, Apr.-Jun. 1997, pp. 517-532.

${ }^{30}$ Karapet Gabikean received in 1913 the Izmireanc' literary prize for his botanical lexicon, Hay busašxarh, "The Armenian Plant-World”, which was published at the St. James' Press of the Armenian Patriarchate of Jerusalem in 1968. It was there that I met his son, Bp. Kiwreł Gabikean (Guregh Kapikian) of blessed memory. Bishop Guregh, who served for decades as the much-beloved principal of the school in the Armenian Quarter, used to offer his guests chocolates and glasses of sweet liqueur while showing them the models he had painstakingly constructed of the churches of Armenia. He inscribed to me a copy of his father's book. The Kapikian clan are well represented in the United States: Bishop Guregh's three nieces, Melanie, Manya, and Haygan, were friends of mine in Arlington, MA.
} 
had difficulty in deciphering it and applied for assistance to the great linguist Hračeay Ačarean, a pupil of Antoine Meillet. In his monograph on the Armenian alphabet, Ačarean writes that when at first Gabikean found he could not read it, "he turned to persons versed in the Book of the Six Thousand (ka dimē Vec'hazareaki hmut anjeru), as well as to a number of master goldsmiths, particularly to the gunsmiths Oskehan and Gēorg Ekkeahean. They informed him that the letters in question were called the Script of the Dove (Aławnagir) and provided the shapes of a few more, that indeed corresponded to the physicians' alphabet ( $b \check{z}$ škaran). The latter also stated that his father and grandfather used to employ those characters as a cryptogram and they still possessed some of those writings. But since, they said, they had taken an oath to their masters (varpetnerun erdum tuac en eter), they would not reveal the secret of the cryptogram (cackagrin gałtnik's erewan č'en haner)." Gabikean saw also a MS with another cipher in which the Armenian letter inni, "I", was represented by the umlauted Latin letter I, $\ddot{i}^{31}$ Another cipher Ačarean studied he termed Dawt"ean, "Davidic", because of its attribution in MSS to the fifth-century Armenian Dawit" Anyałt", "David the Invincible [Philosopher]". ${ }^{32}$ Armenian MSS sometimes attribute to the latter authorship of the magical text Eawt"nagreank', "[The Book of the] Seven Letters" (i.e., the vowels); this text is often found in proximity to the similar Vec ' hazareak. ${ }^{33}$ Thus, the Armenian hetaerogram shares a number of features cognate to those we have observed in other cases: it is a simple substitution cipher; it has some letters in common with other ciphers of the same language; its users claim antiquity and prestige for it; it is associated with magico-mystical practice; it has been in use for centuries (from at least the $16^{\text {th }}$ till the $19^{\text {th }}$ ); and it was used till recently by privileged sub-societies - doctors, goldsmiths, gunsmiths, and magicians. Presumably the use of it as a para-linguistic mode of identity enhanced their own sense of cohesion and self-worth - useful survival tactics for Armenians existing as a minority people in a Muslim state. And though the characters

\footnotetext{
${ }^{31}$ Hračeay Ačarean, Hayoc' grerz, Vienna: Mxit'arean tparan, 1928, pp. 472-473. For a table of this and other Armenian substitution ciphers, as well as published examples of enciphered text, see Plates 15-18.

${ }^{32}$ Ibid., p. 474.

${ }^{33}$ On these magical texts, see J.R. Russell, "The Book of the Six Thousand: An Armenian Magical Text," Bazmavep 147.1-4, Venice, 1989, pp. 221-243, repr. AIS, pp. 319-341; and J.R. Russell, "Maštoc' the Magician," in Sergio La Porta and Theo Van Lint, eds., Festschrift Michael Stone (in publication).
} 
themselves are laden with symbolic significance, the messages of the texts themselves are mundane. It is their script that ennobles them.

Ačarean noted with respect to the designation aławnagir, "script of the dove", that it must belong to such expressions as cti lezun, "language of the sparrow" (Arm cit), for a secret language. ${ }^{34}$ But the dove is no common fowl; it is the bird of the Holy Spirit. So one recalls that a legendary cosmological text that fell to earth from heaven, the subject of an old Russian spiritual poem, is called Golubinaia kniga, "The Book of the Dove", probably with reference to the Christian image, the original title and lectio difficilior having probably been *Glubinnaia kniga, “The Book of Profound [Secrets?]”. In a study of the Russian poem, I suggested that some of its identifiably Zoroastrian features might have come into the Slavic world via the teachings of Armenian followers of the Paulician heresy settled in the Balkans. Perhaps the Armenian designation of the "Script of the Dove" has a parallel meaning to the Russian "Book of the Dove": the latter is the written revelation of the Holy Spirit; the former, the latter, the script used for such writing. For if one examines the characters of the aławnagir, their origin in the shapes of the letters of Armenian minuscule script (bolorgir) is plain; whilst their most striking common feature is the addition of loops or the transformation of the basic shapes so as to incorporate loops. This is, thus, a local development of the Brillenbuchstaben, "Eyeglass [shaped]letters", often found in Jewish and Islamic magical alphabets; examples of the former go back two millennia. ${ }^{35}$ Since the little circles on the ends of the lines of the letters resemble the stars of heaven, such magical alphabets have often been called Angelic scripts: given the association of doves with the Holy Spirit, that might explain in part the designation aławnagir. Though Brillenbuchstaben made directly from the Armenian alphabet of Maštoc' are reserved for ciphers, Pseudo-Arabic Brillenbuchstaben, eyeglass-letter-like asemic symbols, and individual circles probably intended to represent stars are common in Armenian magical MSS. ${ }^{36}$

\footnotetext{
${ }^{34}$ Cited in A.G. Abrahamyan, Hay gri ev grč 'ut'yan patmut' yun, Erevan: Haypethrat, 1959, p. 218.

${ }^{35}$ See Plate 19.

${ }^{36}$ See Plate 20: it is noteworthy that towards the bottom the abbreviations of $T(\bar{e}) r A(s t u a) c$ in standard Armenian letters are adorned with multiple curls and zigzagging endings, a semi-cipher, as it were.
} 
One finally contributes here a hitherto unpublished and curious example of the Script of the Dove. The text comes from the photostat - perhaps fifty years old - of an unidentified MS that was found by chance in November 2008 in a box of old papers at the National Association for Armenian Studies and Research in Belmont, MA, and was kindly placed at my disposal by NAASR's director of academic affairs and my good friend, Marc Mamigonian. The MS is a text of mixed medical and magical content written in a late Classical Armenian suffused with Arabic, Persian, and Turkish botanical and other terms: p. 337 (Plate 21) shows wheels of Life and Death to be interpreted by astrological and numerological operations, and there is a magic square with Arabic numbers; on p. 491 (Plate 22) the capital letter p iwr, Arm. aspirate p', is shown as a naked woman; and on p. 129 (Plate 23) the names of various plants and other materials used in medicine are shown in a cross-hatched pattern reminiscent of the manner in which the sign of the Holy Cross is regularly multiplied (and various sacred Crosses, named) in the texts of Armenian talismanic scrolls (hmayil). On p. 398 (Plate 24), the Armenian date $\dot{R} \check{C} € A=1191$ is inscribed in the upper right hand corner, i.e., AD 1742, along with a long list of the writer's debts: e.g., młsi abrahamin partim třš, that is, "I owe Abraham the pilgrim to Jerusalem (małtesi=muqaddasī) [one] kuruş (łuruš)." On p. 160 (Plate 25) is an inscription in aławnagir: ew mat'usałay grič's yišec 'ék' $i$ k'ristos/ mat'usałay č'nč 'in caray p'arkč 'in "and remember me, the scribe Methuselah:/ Methuselah, the least slave of Christ." The idiosyncratic features of the form of the cipher here are the letter $c a$, Arm. c, represented as a T above a small circle (as in Erevan Matenadaran MS 8360, fol. 570 b); $k^{\prime} \bar{e}$, Arm aspirate $k^{\star}$, as one triangle inverted over another; and se, Arm. s, as an inverted triangle. But overall the cipher is instantly recognizable. The author of the cipher text seems to have taken advantage of empty space on the page for his colophon, and he has also inscribed the Latin alphabet in a cursive hand of the $18^{\text {th }}$ century, followed by a heterogram, the ampersand. And he transcribes his cipher text into a kind of Latin plain text: \& maduocagay qrigc yihecr ikricdoc/ maduocaga gngin zarae prggin. It is obvious from the transcription of the word for "scribe" as /kričl and of Christ's name as /k'risdos/ that our author spoke Western Armenian; and this would make our MS an important early primary attestation in a foreign script of the pronunciation of that dialect. The transcription of $t^{\prime} o$, Arm. aspirate 
$\mathrm{t}^{\mathrm{t}}$, as Latin $\mathrm{d}$ in the author's name probably reflects not an actual pronunciation, but hypercorrection, it would seem.

There is no secret content to the encoded text. So unless Methuselah thought the Latin alphabet a cipher itself - which hardly seems likely, since he has taken the trouble to provide it all, including letters he does not use in his transcription - the use of the Script of the Dove here is more a demonstrative sign that the writer was qualified to be a member of the medical fraternity, than an attempt to conceal sensitive information in code. (But of course it did not hurt that the ignorant would be unable to identify his colophon, erase it, and insert their own in its stead!) That is, although he has employed a heterogram (\&), his Latin allography is proof enough, were extra proof required, that his cipher is a hetaerogram, not a cryptogram. As we have seen, in the general scheme of invented alphabets these writing systems of a sub-society occupy a peculiar place: though not strictly secret, they lend the charisma of the occult and the arcane to mundane writing, as here, in a natural tongue. They also offer dignity and cohesion to people subject perhaps to social indignity, their sense of cohesion threatened by their lack of political power. Although his name was most likely bestowed upon him in wishful thinking by parents anxious that their son live long, the script, at least, that our $18^{\text {th }}$ century Methuselah has used has a pedigree, both actual and invented, to rival the age of his Scriptural namesake. And the hetaerogram of doctors, goldsmiths, and gunsmiths, the Script of the Dove, endured for at least a century and a half beyond, down to the eve of the First World War, in Sebastia and in other ancient cities of that hoary land where first the gentle dove returned with an olive branch of peace in her beak, for the travelers in the Ark: Armenia.

\section{LIST OF PLATES.}

1-3: The Folger MS: key and samples of text.

4-7: Still life painting with incised encrypted texts.

8-12: Cipher page from the notebooks of Daniil Kharms; Kharms' monogram of Osiris (cf. Dee's Monad) with cipher characters; Kharms' drawing of the Tree of Life of the 
Kabbala and table of the Hebrew alphabet with cipher text and symbolic meanings of the letters in Russian; key to Kharms' cipher.

13-14: Golden Dawn cipher MS key and fol. 33 with Dee’s Hieroglyphic Monad.

15: Table of Armenian ciphers, from Hrač ya Ačaryan, Hayoc ' grerə, Erevan: Erevan University Press, 1984, following p. 676.

16: MS facsimile of enciphered text, from A.G. Abrahamyan, Hay gri ev grč $u t^{\prime} y a n$ patmut'yun, Erevan: Haypethrat, 1959, pp. 222-223.

17: Abrahamyan, ibid., pp. 220-221: key to the bžškakan cackagrut 'yun "physicians' cipher".

18: Inscription in b̌̌škakan cackagrut 'yun "physicians' cipher" added in AD 1722 to Armenian Patriarchate of Jerusalem MS 1000, Commentary on the Breviary (Meknut 'iwn žamakargut'ean) of Movsēs Erznkac'i, copied in AD 1706: Abp. Norayr Pōłarean (Bogharian), Mayr C'uc'ak Jeriagrac'Srboc'Yakobeanc', Vol. 3, Jerusalem: St. James' Press, 1968, p. 619.

19: Hebrew Brillenbuchstaben, from Abraham de Balmis, Grammatica hebraea, Venice, 1523, in H.A. Winkler, Siegel und Charaktere in der muhammedanischen Zauberei, Studien zur Geschichte und Kultur des islamischen Orients, Heft VII, Berlin: Walter de Gruyter, 1930, p. 166.

20: Armenian MS with "eyeglass" symbols: Armenian Mxit'arist monastery of S. Lazzaro, Venice, MS 3042, AD 1779, a paper talismanic scroll (hmayil): from Frédéric Feydit, Amulettes de l'Arménie Chrétienne, Venice: S. Lazzaro, 1986, fig. 80.

21: NAASR MS, p. 337.

22: NAASR MS, p. 491.

23: NAASR MS, p. 129.

24: NAASR MS, p. 398.

25: NAASR MS, p. 160. 